Martin Franz, Martina Fuchs* and Sebastian Henn

\title{
Othering practices toward new firm owners: empirical insights from South-North firm acquisitions in Germany
}

https://doi.org/10.1515/zfw-2017-0037

Received: November 15, 2017; accepted: March 8, 2018

Abstract: By dealing with the process of othering in the context of acquisitions, this paper seeks to expand the concept of othering to Economic Geography. It argues that multinational companies should not only be viewed as victims of othering in that they suffer from obstructive policies and hostile public opinion, but rather that othering also matters within such firms. As a consequence of the links they establish between different countries, employees in such companies are constantly confronted with various socio-cultural backgrounds and frequently develop rather different expectations of how their counterparts should perform. This contribution analyses how and why managers and works councils in Germany practice distancing or othering towards owners of German firms located in China and India. It shows that othering can be critical within foreign direct investments. We approach the issue of othering by focusing on the sense of superiority of the involved parties, their positions in the company organisation and their related professional ethics, as well as the dynamics of othering that are mobilised in critical situations. The analysis is based on qualitative interviews from two different research projects.

Keywords: emerging economies; FDI; Germany; industrial relations; othering.

\footnotetext{
*Corresponding author: Martina Fuchs, Wirtschafts- und Sozialwissenschaftliche Fakultät, Universität zu Köln, Albertus Magnus Platz, 50923 Köln, Germany, e-mail: fuchs@wiso.uni-koeln.de Martin Franz: Geographie, Universität Osnabrück, Seminarstr. 19 a/b, 49074 Osnabrück, Germany Sebastian Henn: Lehrstuhl für Wirtschaftsgeographie, Institut für Geographie, Friedrich-Schiller-Universität Jena, Löbdergraben 32, 07743 Jena, Germany
}

\section{Introduction}

Who and what Others are [...] is intimately related to "our" notion of who and what "we" are. "We" use Other to define ourselves: "we" understand ourselves in relation to what we are not.

Kitzinger/Wilkinson 1996, 8

Multinational companies, prominent drivers of globalisation, are increasingly facing a seemingly anti-globalising world. They are challenged by rising protectionism (Sauvant 2009), the reawakening of economic nationalism (Kim 2007), the reinvigoration of populist policies (Globerman 2017) and the strengthening of regional autonomy movements (McDonald et al. 2015). Economic, social and political borders are rising. A key element accompanying these processes is what is commonly known as othering, in other words the demarcation of the counterpart, often associated with a (felt) sense of superiority on the part of the individual or group that 'others'. Othering can thus be understood as a specific type of distancing that creates social space between the self and the other (Kitzinger/ Wilkinson 1996). More than distancing, however, othering focuses on practices mobilised in a particular critical situation to construct hierarchies.

Othering and related concepts and notions, such aslike prejudice, stereotypes, social exclusion and identity, have long been the subject of contributions in the humanities and social sciences (cf. Bauman 2004). International business studies, particularly contributions about mergers and acquisitions (M\&A), have also addressed such topics for decades, predominantly in the context of socio-cultural frictions in company takeovers (cf. Rottig et al. 2013).

Given the recent reawakening of ethnocentrism, economic nationalism and separatism, current research has again become aware of 'the other's other' (Hollington 2017). The contribution at hand argues that it is worthwhile for economic geographers to address the issue of distancing and othering in the context of transnational firm acquisitions, as this offers insights into the hidden mechanisms of how powerful actors within companies (as managers, workers, unions etc.) construe socio-cultural differences that can affect corporate success and exis- 
tence. By so doing, it allows for a better understanding of interspace (i.e. socially produced space in transnational companies; Fuchs et al. 2017) with all its frictions, gaps and processes of rapprochement. We argue that by applying the concept of othering, economic geography can also contribute to the interdisciplinary debate about socially constructed space by addressing the economically and politically relevant spheres of transnational companies. Furthermore, related knowledge about cross-border linkages can help to understand the specific hurdles of transnational investments based on the perception of the involved actors.

We concentrate on the fact that multinational companies are not only (passive) victims of othering in that they suffer from obstructive policies and hostile public opinion, but that othering also matters within such firms. Having locations in different parts of the world, multinational firms establish links between different regions and countries. As a consequence of this, individuals working in such companies are constantly confronted with and shaped by various socio-cultural backgrounds and frequently develop rather different expectations of how their counterparts should perform.

Distancing and othering appear to be of particular importance in the case of brownfield investments, that is when a firm is acquired by a foreign investor. In fact, brownfield investments can threaten existing jobs, primarily in cases of unfriendly takeovers (cf. Golinski/Henn 2015; Golinski/Henn 2017). M\&A-studies report that the success of such acquisitions strongly depends on synergies between the partners and the sensible integration of actors within the new organisation (Ghosh Ray/Ghosh Ray 2013). Evidence suggests, however, that it is often hard to achieve a fruitful collaboration in the new unit. Instead of this, several forms of othering can be observed in many cases. This is often even the case if the acquired firm is located only just across the border (Öberg 2017), though practices of othering appear to be much more relevant if the involved parties are located in different socio-cultural settings, as is the case in South-North investments.

Investments from the South have been spreading throughout Europe and North America for almost two decades with an increasing number of investors from emerging economies acquiring long-established manufacturing companies in the traditional core economies of the Northern hemisphere (Duysters et al. 2015). Following the USA, Switzerland, the United Kingdom and France, China has become the fifth important foreign direct investor in Germany while India ranks sixth in this comparison (KPMG 2018, 9-11). Investors from emerging economies primarily invest in firms belonging to sectors that are key to Germa- ny's international competitiveness (KPMG 2018), such as machinery and automotive industries.

Though there have been only few studies in economic geography that have dealt with issues of distancing and othering in investments between such newcomers and the established core economies (cf. Franz et al. 2017; Golinski/ Henn 2015; Golinski/Henn 2017), most existing studies focus on the investors' side of South-North multinationals (Graebner/Eisenhardt 2004; Kivijärvi/Eriksson 2013; SI et al. 2013) and usually ignore the acquired firms in the North (cf. Fuchs/Schalljo 2016).

To address this research gap concerning distancing and othering in South-North investments practiced by different parties of the acquired Northern firms, the contribution at hand aims to answer the following research question: How and why do managers and works councils in Germany practice distancing or othering towards new firm owners located in China and India?

In cases in which firms from emerging economies like India and China seek to acquire companies in industrialised countries, it is highly probable that employees and managers of the targeted companies will apply practises of distancing or othering (Knoerich 2000). These parties expect the investors to extract 'advantage from the target rather than transferring advantage to the target' (Madhok/ Keyhani 2012, p. 32). Knoerich (2010) has identified several factors that worry stakeholders in the targeted companies. These are cultural and institutional distances, fears about hidden agendas and the perception that firms from the Global South lack the capabilities and competitiveness to successfully lead a company in an industrialized country. These factors seem to be of particular importance in the case of unknown investors from distant countries.

This contribution focuses on distancing or othering practiced by management and works council representatives of the acquired German firms. While the authors have separately analysed managers and works councils elsewhere (Bollhorn/Franz 2016; Franz et al. 2016; Fuchs/ Schalljo 2016; Franz et al. 2017; Fuchs/Schalljo 2017a), this paper is the first to combine and compare both perspectives. Unlike previous contributions, this contribution focuses on the role of distancing and othering in firms taken over by Southern investors. In the following, we suggest applying a new heuristic framework to economic geography that is inspired by the othering debate in the humanities and social sciences, and includes insights from research on M\&A. We approach the issue of othering by focussing on the relationships of subordinates and superiors between the involved parties (cf. Risberg et al. 2003), their positions in the organisation and their related professional ethics, as well as the dynamics of othering mobil- 
ised in critical situations. Following some methodological comments, the empirical part of this paper focuses on distancing or othering practiced by management and work council representatives of the acquired German firms. The conclusion sums up the results and integrates them within the broader academic debate.

\section{Toward an economic geographi- cal concept of othering}

To date, a number of studies in the broader area of human geography have addressed different issues of othering. This includes studies in urban geography (e.g. Leitner/ Sheppard 2013), tourism geography (e.g. Steinbrink 2012), political and post-colonial approaches in geography (Lossau 2002; Valentine 2010) as well as in studies about work, migration and gender (e.g. McDowell 2008). While in economic geography othering has been touched on in several studies, for example in terms of socio-cultural gaps (Depner/Bathelt 2005), frictions bridged by boundary spanning (Schotter et al. 2017), perceived distances (Torre/ Rallet 2005; Si/Liefner 2014; Walcott/Liefner 2017) and conscious strategies (Suwala/Kulke 2017), a systematic analysis of this concept is still missing.

In economic geography, distance (and proximity), which can be viewed somewhat similar to othering, has been differentiated along various dimensions. While innovation has been the core epistemic interest of the so-called proximity debate, particularly in the context of cross-border economic relations (cf. Balland et al. 2015), terminological concepts that have emerged in this context cannot be easily transferred to the othering debate. Still, some insights of the proximity debate allow for a better understanding of the relationships between the counterparts in transnational endeavours (Table 1 highlights some key publications about related concepts without claiming to give a comprehensive overview of the broad interdisciplinary debate). In the following section we relate the debate on othering and distance to the existing knowledge about this subject matter in M\&A studies. In doing so we emphasise three issues that we consider to be crucial for the analysis of othering in cross-border investments in economic geography: (1) sense of superiority, (2) position in the organisation and related professional ethics and (3) dynamics in critical situations.

\subsection{Othering: sense of superiority}

In general, othering can be regarded as a specific type of distancing in that it creates social space between the self and the other (Kitzinger/Wilkinson 1996). In principle, some distance between 'me' and 'you' is necessary for an active and resilient self and an appropriate togetherness (Schulz-Nieswandt 2017). Still, othering often also implies a sense of superiority of a person, group, community or part of a population over others. Therefore, othering not only means to set oneself (and the group to whom one feels related) apart from 'the other', but also to feel as if one is in a (somewhat) superior position. This idea of othering is critical as it does not refer to a relationship between 'me' and a (somewhat) close 'you' but rather between 'me' and a rather remote third person with a felt objectification of the counterpart and the ignorance of the peculiarities of the individual or group (Dervin 2012). In these cases, othering creates a boundary between the own identity and the other and can be regarded as the mechanism that measures the counterpart against the self which is regarded as superior (van Houtum/van Naerssen 2002) and negatively brands someone or some group as 'the other' (Dervin 2016). This means that the other is typically regarded as deviant, inferior and marginal (Little 1999) or even impure (Chaturvedi 2002) and dehumanised (Dervin 2016). Based on this, we argue that a sense of superiority is a crucial dimension of othering, while the debate about distance and proximity typically does not take this issue into account.

In economic geography, proximity studies do not explicitly deal with issues of (alleged) superiority. However, the discourse clearly addresses related issues of mistrust, insufficient kinship, unclear mutual experiences, misunderstandings (Boschma 2005) and various dissimilarities on the micro-level of the firm (Grabher/Ibert 2014; Ibert/ Müller 2015). Moreover, the key categories of social and organisational distance include matters of perceived superiority and informal hierarchies (Torre/Rallet 2005). Such issues need further elaboration and adaptation with regard to acquisitions.

In this context, M\&A studies offer examples for othering in international firm acquisitions, even if they do not address a comprehensive concept of othering. Several works have discussed related issues with regard to threats to organisational identity (e.g. Gertsen/Søderberg 1998; Gertsen et al. 1998), employees' scepticism toward new owners (Bollhorn et al. 2016; Dick et al. 2006, 69), a lack of synergy (Larsson/Finkelstein 1999), rotations of managers and employees (Krug/Nigh 2001; Chambers/Honeycutt 2009) and low work performance (Wishard 1985; Davy 
Table 1: Relationships between othering and related concepts.

\begin{tabular}{|c|c|c|c|}
\hline & Definition & Relation to the concept of othering & References \\
\hline Othering & $\begin{array}{l}\text { Sense of creating social space between } \\
\text { the self and the other. Othering is the } \\
\text { mechanism that negatively brands the } \\
\text { other as the other in terms of subject } \\
\text { positions, status, socio-cultural identities, } \\
\text { domination etc. }\end{array}$ & & $\begin{array}{l}\text { Kitzinger/Wilkinson 1996; } \\
\text { Koveshikov et al. } 2017\end{array}$ \\
\hline Distancing & $\begin{array}{l}\text { Creating social space between the self and } \\
\text { the other }\end{array}$ & $\begin{array}{l}\text { Othering denotes a specific kind of } \\
\text { distancing. More than distancing, othering } \\
\text { focuses on practices mobilised in a } \\
\text { particular critical situation to construct } \\
\text { hierarchies. }\end{array}$ & Kitzinger/Wilkinson 1996 \\
\hline $\begin{array}{l}\text { Distance/ } \\
\text { proximity }\end{array}$ & $\begin{array}{l}\text { In economic geography, no general } \\
\text { definition of distance and proximity exists. } \\
\text { Instead, different types of proximity have } \\
\text { been defined, for example by Boschma } \\
\text { (2005) who distinguished between cog- } \\
\text { nitive proximity, organizational proximity, } \\
\text { social proximity, institutional proximity and } \\
\text { geographical proximity }\end{array}$ & $\begin{array}{l}\text { The notion of distance does not explicitly } \\
\text { distinguish between creating distance } \\
\text { in the sense of 'somewhere else' or } \\
\text { 'far away' and the more critical issue of } \\
\text { alleged superiority, which is considered } \\
\text { part of the concept of othering. Social and } \\
\text { organisational distance address issues } \\
\text { of othering in economic space related to } \\
\text { the degree of integration (membership } \\
\text { to the same organisational entity and the } \\
\text { ability of an organisation to make their } \\
\text { members interact and develop a feeling of } \\
\text { belonging). }\end{array}$ & $\begin{array}{l}\text { Boschma 2005, Balland } \\
\text { et al. 2015, Ibert 2010; } \\
\text { Torre/Rallet } 2005\end{array}$ \\
\hline $\begin{array}{l}\text { Superiority/ } \\
\text { inferiority }\end{array}$ & $\begin{array}{l}\text { The terms are used by different authors } \\
\text { either to relate to the perception of } \\
\text { identities (Risberg et al. 2003) or to } \\
\text { compare specific objective characteristics } \\
\text { of the different companies involved in } \\
\text { a merger, for example in terms of brand } \\
\text { portfolios and market shares (Königs/ } \\
\text { Schiereck 2008) }\end{array}$ & $\begin{array}{l}\text { Superiority is one dimension of othering } \\
\text { as othering implies a sense of superiority } \\
\text { of a person, group, community or part of a } \\
\text { population over others. Therefore, othering } \\
\text { does not only mean to set oneself apart } \\
\text { from 'the other', but also feeling that one is } \\
\text { in a superior position. }\end{array}$ & $\begin{array}{l}\text { Risberg et al. 2003; } \\
\text { Königs/Schiereck } 2008\end{array}$ \\
\hline Stereotypes & $\begin{array}{l}\text { The term 'stereotypes' is often used both } \\
\text { in M\&A literature (e.g. Vaara/Tienari } \\
\text { 2011) and in a colloquial sense to denote } \\
\text { somebody's perception of what someone } \\
\text { else is like. This categorical thinking helps } \\
\text { to simplify the own perception based on } \\
\text { pre-existing beliefs about the surrounding } \\
\text { social world, while also degrading the } \\
\text { 'other' and thus improving the self-image }\end{array}$ & Stereotypes are a specific form of othering. & $\begin{array}{l}\text { Risberg et al. 2003, Vaara/ } \\
\text { Tienari 2011; } \\
\text { Macrae/Bodenhausen } \\
\text { 2000; Koveshikov et al. } \\
2016\end{array}$ \\
\hline
\end{tabular}

et al. 1988). Studies have reported that takeovers often cause negative reactions on the side of the employees (e.g. Jemison/Sitkin 1986; Schweiger/Denisi 1991) and even resistance (e.g. Bollhorn/Franz 2016; Franz et al. 2017) indicating that such behavioural patterns have the potential to undermine the entire endeavour (Huter et al. 2017).

\subsection{Position in the organisation and related professional ethics}

Besides social distance, the concept of organisational distance (Balland et al. 2015; Boschma 2005), and specifically the debate on organisational-relational practices (Ibert 2010; Torre/Rallet 2005), also addresses issues of othering in the economic space. Such studies relate to the degree of integration, that is membership in the same organisation- 
al entity (Balland et al. 2015; Boschma 2005), and the ability of an organisation to make its members interact and develop a feeling of belonging (Torre/Rallet 2005). They highlight the difficulties that appear if the parties involved have to interact across boundaries as they are affiliated with different organisational units (Ibert/Müller 2015).

M\&A studies, by contrast, are more precise with regard to the concrete roles of managers and employees (cf. Ivancevich et al. 1987; Buono/Bowditch 2003; Dick et al. 2006), which is not surprising given the interest of the proximity debate in innovation on the one hand and the M\&A debate in successful M\&As on the other hand. However, in both discourses, the deeper psychosocial mechanisms related to the actors' positions within the firm, which drive othering practices, have hardly been addressed.

According to Oevermann (2001), individuals' social practices are guided by patterns of interpretation; these are mutually shared, normative and usually implicit patterns influencing how individuals perceive the world and how they act. Othering is one such implicit pattern of interpretation that comes to the fore and is mobilised as practice in critical situations (Fuchs/Schalljo 2017a).

Othering and many other patterns of interpretation are spread broadly throughout society. Some are prevalent in particular professions and thus organisational positions (cf. Oevermann 2001). The position somebody has in an organisation often relates to particular professional ethics, as the examples of company managers, trade unionists, medical doctors, nurses, lawyers suggest. Individuals are socialised and habitualised in particular vocational schools, universities, meetings, and so forth, and are thus educated in and shaped by particular social environments. German managers, for example, are shaped by particular Western professional ethics (Bathelt/Gertler 2005; Gertler 2001). Their relevant identity markers include the efficiency and functionality of their work organisations, and their self-beliefs as cosmopolitan doers who can master all challenges and who care for 'their' firm and thus the employees (Fuchs/Schalljo 2016). Just like managers are socialised in particular ways so are the labour representatives (cf. Cumbers et al. 2008). In Germany, trade unionists and works council members attend meetings in which they are encouraged not only to defend the employees' rights but also to practice international solidarity. Furthermore, works councils in Germany usually have a clear commitment to support the economic success of the company (cf. Meyer/Fuchs 2010). Without any doubt, the professional ethics result in the rise of tensions, for example, if the cosmopolitan openness (managers) and international solidarity (works councils) is set against the ef- ficient and responsible corporate organisation to support the survival of the firm (managers and works councils). We therefore argue that the position in the organization and related professional ethics is the second crucial dimension when it comes to understanding and analysing othering, beyond sense of superiority as first dimension.

\subsection{Dynamics in critical situations}

Usually, patterns of interpretation bear latent characteristics. In critical situations, particular patterns of interpretation are 'mobilised', or activated, which result in different social practices (cf. Oevermann 2001). Managers or works council members, who may feel challenged by a critical event like a takeover, can mobilise the (latent) patterns of interpretation to better deal with the problem they are confronted with. Then, for instance, pluralistic attitudes and cosmopolitan practices can yield to self-demarcation (Fuchs/Schalljo 2016). Against this background, we regard critical situations as the third crucial dimension of othering.

The focus on critical situations that have the potential to mobilise othering practices also suggests adopting a dynamic perspective. The proximity debate focuses on dynamics by identifying stages of organisational learning and steps of different collaborative constellations during the innovation process (Ibert 2007; Ibert/Kujath 2011). Additionally, the M\&A debate focuses on stages, albeit with a much stronger focus on the question of how the partners involved in M\&As approach one another. The literature on M\&A suggests typical pathways through which acquisitions pass in the course of time. The process starts, for example, with the early announcement of an acquisition that potentially causes negative reactions in the firm to be taken over (e.g. Jemison/Sitkin 1986), followed by what could be called the honeymoon stage and finally the daily routine of the marriage partners in the later post-merger stage (Cartwright/Cooper 2001), or the counterparts' revaluation as a (still exotic) friend (cf. Steinbrink 2012). While such stage models may be supported by particular cases, the direction and the dynamics of M\&A vary considerably, thus questioning such simplistic models. The path of integration is, for example, influenced by the role of the investor (money spender or rationaliser), the firm history (former changes of firm ownership) and the communication between managers and workers (Bollhorn/ Franz 2016; Franz et al. 2017). In this paper we do not suggest a one-size-fits-all model of steps, but rather focus on the dynamics in the critical stage of the pre- and the early post-acquisition stage. Such a focus is particularly inter- 
esting, as othering practices are likely to be realised in critical stages and therefore can be expected to be expressed in interviews. Moreover, a focus on the pre-acquisition and early post-acquisition stage is adopted as Chinese and Indian acquisitions are still a rather young phenomenon in Germany.

\subsection{Basic insights of the conceptual deliberations}

Othering is a specific type of distancing that clearly denotes (felt) superiority over the other, which is not necessarily the case in the superordinate concept of distancing. More than distancing, othering focuses on practices mobilised in particular critical situations to construct hierarchies with an (alleged) objectification of the other and the ignorance of the other's peculiarities. As these social patterns of interpretation frame the practices of individuals, they determine how they react in the case of an acquisition. Within firms, the mobilisation of othering strongly depends on how the position holder (manager or works council representative) is bound by particular professional ethics and by the specific path of integration defined by the strategy of the investor, the firm history and the communication between managers and workers. The means of communication especially enables stakeholders affected by an acquisition (investors, managers, representatives of labour) to reduce othering. While othering is a stable latent pattern of interpretation, the way it expresses itself in practice depends on how the particular actor is involved in a critical situation. To analyse such social patterns of interpretation, qualitative approaches are meaningful as they allow for a differentiated analysis of the content and the enunciation of the interviewed persons. The three issues that we consider crucial for analysing othering in cross-border investments identified above-sense of superiority, position in the organization and related professional ethics and dynamics in critical situations-will be applied in the following analysis.

\section{Methodological comment}

Our contribution refers to insights from two independent research projects carried out in the early 2010s. Both projects applied qualitative approaches and understand interviews as performed practices construed in space. Thus, rather than considering the regional effects of acquisitions on further spatial dimensions, such as the local labour market, this article understands distancing and othering as latent patterns of interpretation that can be mobilised as realised (spoken) practices in critical situations. This is in line with research that considers cross-border investments as discursive struggles and notions about the linguistic and discursive nature of micro-political practices and power relations in cross-border spaces (Koveshnikov et al. 2017).

The results combine methods of structural hermeneutics (Oevermann 2001) and qualitative content analysis (Mayring 2007) applied in both projects. The project "Managers' Patterns of Interpretation of Takeovers and Majority Stakes by Foreign Investors" (2013-2017, empirical studies carried out in 2014/2015) focused on German managers' interpretations of M\&A-investors from emerging economies. This article refers to ten interviews of this project that were carried out with eight German companies. The companies had been acquired by investors from emerging economies (five Chinese and three Indian takeovers). They focused on acquisitions of medium and large companies in Germany that took place between 2009 and 2014. The interviews lasted between 60 and 120 minutes. In 2016, the firms were analysed in a follow-up survey to deepen the insights about the initial post-merger process. All interviewees had experienced a similar socialisation and had their professional ethics shaped by a similar mind-set as they were born in Germany respectively had lived there for a long time. In addition, most of the companies analysed represent a type of manufacturing company with a long-standing tradition in German management culture in that they were formerly owned by big firms such as BASF, Hochtief, Thyssen, and Siemens.

The project BRICINVEST ("Investors from the BRIC states and workers ' interests in Germany") assessed how the work and labour relations in German firms were affected by such investments. Among other things, it included 43 qualitative interviews with managers and representatives of works councils of 27 German firms that were acquired by Chinese (36 interviews in 20 different firms) or Indian (seven interviews in seven different firms) firms mainly from the automotive and machine engineering sector and another 28 interviews with trade union representatives, consultants and counsellors. The interviews were conducted in 2013 and 2014 and lasted between 60 and 90 minutes. Relevant interview excerpts from these interviews were translated from German to English.

Both studies applied qualitative approaches, were conducted in almost the same period of time and analysed the perceptions of different actors of the same types of investments and companies. As such, the results are not 
only complementary but allow for a comparison in terms of the managers' and collective agents' perceptions.

\section{Empirical findings}

In the following, the othering practices of German managers and works councils are analysed. For this, we apply the concept of othering as discussed above.

\subsection{Managers}

All interviewed managers stressed that they initially welcomed the investors from China or India especially as they endowed their firms with new capital. Given their position within the company, the German executives started the acquisition process. They believed themselves to be socio-culturally open managers and capable doers on an international stage, and to be able to bridge expected organisational and social distances to any relevant economic partner irrelevant of the counterpart's country of origin. In the interviews they further expressed that they saw themselves as the ones responsible for the future of the firm and their employees.

However, after the acquisition, the managers typically experienced that the new owners did not act in compliance with existing global management procedures. The interviewees reported various difficulties that appeared in daily interactions during the post-acquisition stage based on organisational distance. They stated, for example, that Chinese investors regarded hierarchical patterns as more relevant than efficiency, and that the Chinese owners 'hardly accept issues if we speak bluntly' (interview with a German manager in a Chinese takeover, 2014). Furthermore, the interviewees regarded the way the new owners handled the administration as ineffective as the investors often did not apply established management schemes, did not prioritise objectives, and did not follow common lines of reporting. All in all, this made German managers regard the foreign investors as inexperienced counterparts. As a corollary, they saw themselves in the role of superior masters, as is exemplified in the following quote: 'Well, I think in every respect the Chinese can learn a lot from us, really a lot' (interview with a German manager in a Chinese takeover, 2014). In cases in which it became obvious that the counterpart was unwilling or incapable to learn, the tone became harsh, as becomes evident in the following interview excerpt: 'This is, for a German manager, who is aware of defined decision making processes, and who cares about them, and is educated in this manner-to our culture this is partly an imposition' (interview with a German manager in a Chinese takeover, 2014).

The quotes clearly indicate a (felt) boundary between the own identity and the other and that the interviewees measure the counterpart against the norms of the self (cf. Dervin 2016). Expressions about the managers' 'care', the reference to the interviewee being 'educated in this manner' and the reference to 'our culture' denote clear identity markers. The other is perceived as being in a subordinated position illegitimately acting at the same level as the interviewee-a situation that causes problems ('imposition').

At the same time, the interviews revealed the managers' surprise about their own othering practices. In fact, they did not expect the takeovers to mobilise othering practices. Rather, they emphasised that they primarily would like to have a counterpart on a level playing field. Still, by seeing themselves as better skilled and as the ones competent to succeed in further developing the firm, othering by strategically keeping the investor out of daily decision-making became the predominant management principle. Further, interviewees referred to their counterparts who were established in their company as to the 'foreign body'. The interviewees retrospectively related their othering practices to the fact that the young and inexperienced investors from the South had bought a company that included competent German managers in need of broad manoeuvring room for decision-making.

Given their initial beliefs about themselves as cosmopolitans, the managers felt conflicts between their self-images and their othering practices in daily work life. Examples of rapprochement were particularly apparent in cases in which the new owners were perceived as individuals having similar professional ethics. One interviewee produced a differentiated image of 'China' and of the other, 'If you ask me now, is it a Chinese investor? No, because the company is from Hong Kong. [...] With headquarters in Singapore, and the management has a proper European education' (interview with a German manager in a Chinese takeover, 2014). However, this was rather an exception. Most of the managers practiced some form of othering and legitimised their practices by referring to the necessity of acting in terms of the principles of economic rationality, which they assimilated with their professional education (cf. Fuchs/Schalljo 2017b).

\subsection{Works councils}

Different to the managers who began the acquisition with cosmopolitan attitudes, all interviewed works council 
representatives stated that they and their employees felt insecure and, due to the perceived organisational and socio-cultural distances between them and the foreign investors, were quite sceptical in the early stages of an acquisition. For example, a chairman of a works council (2013) referred to the situation when he first heard that the company would be taken over as follows: 'If the Chinese will buy us then-what are his plans, (...) will he withdraw [our] know-how and then shut down the plants, or what does it mean? They told us: well, this does not go so far. Now there are examples that complete steel factories were broken down here and built up again in China. Thus obviously this is possible. This was a little bit worrying and certainly, logically there was the fear of the deterioration of work conditions, wages and so on (...)'. This quote illustrates the chairman's othering practices by using generalising expressions, such as 'the Chinese' as pars pro toto, which is opposed to 'us' as a generalised label for the firm and the workers (cf. Dervin 2012). At the same time, the quote expresses the deep upset and fears of changes to the existing order. The interviewee mentions the worst case (plant closure) and then opens the view on several challenges that are unforeseeable to him ('or what does it mean?'). Subsequently, the interviewee reports unsatisfactory answers from the company managers ('they told us'), as the German managers clearly tried to calm down him with the information that the process takes time. Given his felt insecurity, he relates to prominent examples of plant relocations from 'here' to China. As the representatives of works councils were confused given the uncertain situation, they practiced othering and associated Chinese companies with, for example, general stereotypes broadly spread in the public, such as being ruthless, being technology thieves, and as undermining social standards (cf. Golinski/Henn 2015).

Othering can also influence the employees' social identification with the company. 'The identification with the company, which used to be very strong before, has changed [after the acquisition by a Chinese investor]. Certainly, it also changed something in the field of motivation' (interview with a works council member, 2014). While social identification with the company can be strongly connected to the original development of attitudes of othering ('We, the company' versus 'them, the investors'), the denigration of the new firm owners applies to the company as a whole after the acquisition.

As mentioned in the conceptual part of this paper, communication between the works council and the foreign investors can be supportive for mutual understanding (Bollhorn/Franz 2016; Franz et al. 2017). However, such exchange is often limited or does not exist at all, 'We have no contact. Not at all. Zero. We do not want to have contact' (interview with representative of works council, 2013).

Obviously, it is not only the language barrier (Chinese to German or English) that gave cause for othering. Moreover, concerns about the forthcoming success of 'their' company connected managers and works councils representatives. Interviews coincidentally indicate that almost none of them saw a clear future strategy of the foreign investor.

However, as in the case of German managers, the dynamics of mobilised patterns of interpretation of the works councils representatives did not show a uniform picture. There were cases in which the investors from China or India had direct contact with the employees and the works council members at an early stage of the acquisition process (even during the negotiations). For example, one member of a works council stated in an interview (2013), 'We have lost an enemy image. He invited the works councils and introduced himself [...] and called the chairman of the works council 'friend'. [...] He has also already listened to us in many personnel decisions. [...] This is a complete paradigm shift for us. [...] From the classic image of an enemy manager of the company [...] towards working together, reasonable working conditions [...]'. In cases in which the 'the frightening other' was positively revalued as 'the exotic, friendly other' (cf. Steinbrink 2012, 232), the employees' and works councils' relationship with the foreign investor changed from a relationship of self-reflexive othering to less judgemental distancing as it lost the dimension of perceived superiority.

Particularly the German management acted as a buffer and intermediary in day-to-day business between the foreign investor and the workforce, allowing the works councils representatives to practice multicultural openness. As the works councils representatives were not involved in day-to-day conflict negotiations between German management and the Chinese or Indian counterparts, their view on the foreign investors was rather vague and abstract and did not need to be proven in daily routines. Later, works council members' practices were less shaped by superiority (othering), as was the case for managers, and more influenced by a perception of the Chinese part as somebody far away (distancing).

\section{Conclusion}

The study analysed how and why managers and works councils in Germany practice distancing or othering to- 
wards owners of German firms who are located in China and India. It argued that othering, mobilised in the critical situation of an acquisition through a foreign investor, strongly depends on the actors' position and their related professional ethics. The results illustrated that managers adopted cosmopolitan attitudes in the pre-acquisition stage and in the stage right after the acquisition. Then, in daily collaboration, they faced clear challenges caused by their Chinese and Indian counterparts and began to practice notable othering. The situation was different to that of labour representatives in the firm taken over. The works councils representatives were challenged by the 'other', that is the unknown and remote investor, in the pre-acquisition and early acquisition stage. In the later post-acquisition process in most cases they were hardly involved in daily interaction with the new investor. Such distance allowed them to adopt a rather open-minded attitude toward the investor. As a consequence, othering gradually turned in distancing shaped by feelings of superiority to a lesser degree.

In general, it becomes obvious that othering practices result from a different view of one's own position and the other (cf. Kitzinger/Wilkinson 1996). Moreover, it sometimes occurs as a sense of superiority that goes along with clear power practices as is suggested by the fact that the other is typically regarded as deviant and inferior (cf. Little 1999; van Houtum/van Naerssen 2002). Obviously, the latter aspect of othering is more critical in terms of economic, social and political relations. Given that a particular degree of rapprochement is considered necessary for successful cross-border acquisitions (cf. Giustiano/de Bernadis 2017; Rottig et al. 2013), the results of this contribution show remarkably strong practices of othering in German management. Even though Chinese and Indian investors often act as money spenders for German hidden champions in high-tech sectors (Knoerich 2000) and thus might accept their role as distant partners for some time, the question remains of how long they will accept the (informally subordinated) role that their German counterparts assign to them as (formal) owners of the firm.

Thus, such ascriptions can change over time. In their studies about Finnish investments in Russia, Koveshnikov et al. (2017) found that their Russian and Finnish interviewees were able to reflect on their othering strategies, thereby construing a new discursive positioning for themselves while at the same time establishing a higher degree of mutual trust.

We suggest that such insights into how actors construe their transnational counterparts are relevant to better understand transnational economic encounters, as othering appears to be a broadly spread pattern of interpretation and practice. Economic geography can benefit from this analysis of the underlying mechanisms that guide how different parties within companies construe differences and power relations. We suggest that by focussing on the (economically and socially important) area of multinational companies, economic geographical research can contribute to the interdisciplinary debate about socially constructed interspaces. Such insights provide academics and practitioners with better knowledge about socio-cultural frictions and rapprochements thus allowing them to better foresee future effects of transnational encounters.

Acknowledgements: This manuscript has evolved in the context of different research projects. The project about managers' patterns of interpretation supported by the German Scientific Foundation (FU 424/15-1) was carried out by Martina Fuchs and Martin Schalljo. The project on work and labour relations, BRICINVEST, was financed by the Hans Boeckler Foundation. It was conducted by Kai Bollhorn, Martin Franz, Sophie Golinski, Sebastian Henn, Reinhard Röhrig and Jörg Weingarten. We thank the supporting institutions as well as Martin Schalljo for his inspiring interpretation of the interviews (his $\mathrm{PhD}$ thesis will be completed in 2018).

\section{References}

Balland, P.A./Boschma, R./Frenken, K. (2015): Proximity and innovation: from statics to dynamics. In: Regional Studies, 49(6), 907-920. DOI: 10.1080/00343404.2014.883598.

Bathelt, H./Gertler, M.S. (2005): The German variety of capitalism: forces and dynamics of evolutionary change. In: Economic Geography, 81(1), 1-9. DOI: 10.1111/j.1944-8287.2005. tb00252.x.

Bauman, Z. (2004): Identity conversations with Benedetto Vecchi. Cambridge.

Bollhorn, K./Franz, M. (2016): Production network knowledge as A foundation for resistance. Workers influence on a Chinese acquisition in Germany. In: Tijdschrift voor economische en sociale geografie, 107(4), 407-420. DOI: 10.1111/tesg.12164.

Bollhorn, K./Franz, M./Kraemer, G. (2016): Willkommen oder Widerstand. Reaktionen von Belegschaft und Repräsentanten. In: Franz, M./Henn, S./Weingarten, J. (Hrsg.): BRIC-Investitionen in Deutschland. Chancen und Risiken für Unternehmen und Arbeitnehmer. Bielefeld, 215-220.

Boschma, R. (2005): Proximity and innovation: a critical assessment. In: Regional Studies, 39(1), 61-74. DOI: $10.1080 / 0034340052000320887$.

Buono, A. F./Bowditch, J.L. (2003): The human side of mergers and acquisitions: managing collisions between people, cultures, and organizations. Washington, D.C. 
Cartwright, S./Cooper, C.L. (2001): Managing mergers, acquisitions and strategic alliances: integrating people and cultures. Oxford.

Chambers, K./Honeycutt, A. (2009): Telecommunications mega-mergers: impact on employee morale and turnover intention. In: Journal of Business \& Economics Research (JBER), 7(2), 43-52. DOI: https://doi.org/10.19030/jber.v7i2.2260.

Chaturvedi, S. (2002): Process of othering in the case of India and Pakistan. In: Tijdschrift voor Economische en Sociale Geografie, 93(2), 149-159. DOI: 10.1111/1467-9663.00191.

Cumbers, A./Nativel, C./Routledge, P. (2008): Labour agency and union positionalities in global production networks. In: Journal of Economic Geography, 8(3), 369-387. DOI: 10.1093/jeg/ Ibn008.

Davy, J.A./Kinicki, A./Kilroy, J./Scheck, C. (1988): After the merger: dealing with people's uncertainty. In: Training \& Development Journal, 42(11), 56-62.

Depner, H./Bathelt, H. (2005): Exporting the German model: the establishment of a new automobile industry cluster in Shanghai. In: Economic Geography, 81(1), 53-81. DOI: 10.1111/ j.1944-8287.2005.tb00255.x.

Dervin, F. (2012): Cultural identity, representation and othering. In: Jackson, J. (ed.): The Routledge Handbook of Language and Intercultural Communication. New York, 243-281.

Dervin, F. (2016): Discourses of othering. In: Dervin, F. (ed.): Interculturality in education. A theoretical and methodological toolbox. London, 43-55.

Dick, R./Ullrich, J./Tissington, P.A. (2006): Working under a black cloud: How to sustain organizational identification after a merger. In: British Journal of Management, 17(1), 69-79. DOI: 10.1111/j.1467-8551.2006.00479.x.

Duysters, G./Cloodt, M./Schoenmakers, W./Jacob, J. (2015): Internationalisation efforts of Chinese and Indian companies: an empirical perspective. In: Tijdschrift voor Economische en Sociale Geografie, 106(2), 169-186. DOI: 10.1111/tesg.12135.

Franz, M./Henn, S./Weingarten, J. (2016): BRIC-Investitionen in Deutschland. Chancen und Risiken für Unternehmen und Arbeitnehmer. Bielefeld.

Franz, M./Bollhorn, K./Röhrig, R. (2017): Industrial relations and FDIs from China and India in Germany. In: Fuchs, M./Henn, S./ Franz, M./Mudambi, R. (eds.): Managing culture and interspace in cross-border investments. Building a global company. New York/London, 33-42.

Fuchs, M./Schalljo, M. (2016): 'Western' professional ethics challenged by foreign acquisitions: German Managers' patterns of interpretation surrounding Chinese and Indian investors. In: Geoforum, (75), 20-28. DOI: 10.1016/j.geoforum.2016.06.017.

Fuchs, M./Schalljo, M. (2017a): Behind the scenes. Managers' interpretations of foreign takeovers by investors of emerging economies. In: Fuchs, M./Henn, S./Franz, M./Mudambi, R. (eds.): Managing Culture and Interspace in Cross-Border Investments. Building a Global Company. New York/London, 24-32.

Fuchs, M./Schalljo, M. (2017b): Global encounters challenge Western rationality assumptions. In: Science as Culture, (26) 4, 520-528 (“Techno-economic Assumptions" Special Forum). DOI: 10.1080/09505431.2017.1354845

Fuchs, M./Henn, S./Franz, M./Mudambi, R. (2017): Managing culture and interspace in cross-border investments: Building a global company. In: Fuchs, M./Henn, S./Franz, M./Mudambi,
R. (eds.): Managing Culture and Interspace in Cross-Border Investments. Building a Global Company. New York/London, 1-9.

Gertsen, M.C./Søderberg, A.M. (1998): Foreign acquisitions in Denmark: cultural and communicative dimensions. In: Gertsen, M.C./Søderberg, A.M./Torp, J.E. (eds.): Cultural dimensions of international mergers and acquisitions. Berlin/New York, 167-198. (=de Gruyter Studies in Organization, Band 85).

Gertsen, M.C./Søderberg, A.M./Torp, J.E. (eds.) (1998): Cultural dimensions of international mergers and acquisitions. Berlin/ New York. (=de Gruyter Studies in Organization 85).

Ghosh Ray, K./Ghosh Ray, S. (2013): Cross-border merger and acquisitions: modelling synergy for value creation. In: Cooper, C.L./Finkelstein, S. (eds.): Advances in mergers and acquisitions. Bingley, 113-134. (=Advances in Mergers and Acquisitions 12). DOI: 10.1108/S1479-361X(2013)0000012008.

Giustiniano, L./De Bernardis, L. (2017): Multiple organisational identities after M\&As. In: Fuchs, M./Henn, S./Franz, M./ Mudambi, R. (eds.): Managing culture and interspace in Cross-Border Investments. Building a Global Company. New York/London, 50-60.

Globerman, S. (2017): A new era for foreign direct investment? In: Multinational Business Review, 25(1), 5-10. DOI: 10.1108/ MBR-12-2016-0047.

Golinski, S./Henn, S. (2015): Imperialisten, Spione oder Retter? Zur Charakterisierung von Direktinvestitionen aus Russland, Indien und China in deutschen Tageszeitungen. In: Zeitschrift für Wirtschaftsgeographie, 59(1), 1-19. DOI: 10.1515/ zfw.2015.0001.

Golinski, S./Henn, S. (2017): Othering FDIs in the media. How Chinese investors are constructed as deviating others in German dailies. In: Fuchs, M./Henn, S./Franz, M./Mudambi, R. (eds.): Managing Culture and Interspace in Cross-Border Investments. Building a Global Company. New York/London, 10-23.

Grabher, G./Ibert, O. (2014): Distance as asset? Knowledge collaboration in hybrid virtual communities. In: Journal of Economic Geography, 14(1), 97-123. DOI: 10.1093/jeg/lbt014.

Graebner, M. E./Eisenhardt, K.M. (2004): The seller's side of the story: acquisition as courtship and governance as syndicate in entrepreneurial firms. In: Administrative Science Quarterly, 49(3), 366-403.

Hollington, A. (2017): The other's other - colonial version and postcolonial subversion in Jamaica. Conference on the Other's Other, Cologne, 25-26 $6^{\text {th }}$ September 2017.

Huter, L./Dao, M.A./Degischer, D./Bauer, F./Stockhammer, Y./ Erlacher, M. (2017): A comparison of German and Austrian inbound and outbound cross-border transactions and the diverging effect of integration of wholly owned target firms. In: Fuchs, M./Henn, S./Franz, M./Mudambi, R. (eds.): Managing culture and interspace in cross-border investments. Building a Global Company. New York/London, 70-87.

Ibert, O. (2007): Towards a geography of knowledge creation: the ambivalences between 'knowledge as an object' and 'knowing in practice'. In: Regional Studies, 41(1), 103-114. DOI: $10.1080 / 00343400601120346$.

Ibert, O. (2010): Relational distance: sociocultural and time-spatial tensions in innovation practices. In: Environment and Planning A, 42(1), 187-204. DOI: 10.1068/a4247. 
Ibert, 0./Kujath, H.J. (2011): Wissensarbeit aus räumlicher Perspektive: Begriffliche Grundlagen und Neuausrichtungen im Diskurs. In: Ibert, O./Kujath, H.J. (Hrsg.): Räume der Wissensarbeit. Zur Funktion von Nähe und Distanz in der Wissensökonomie. Wiesbaden, 9-46.

Ibert, O./Müller, F.C. (2015): Network dynamics in constellations of cultural differences: relational distance in innovation processes in legal services and biotechnology. In: Research Policy, 44(1), 181-194. DOI: 10.1016/j.respol.2014.07.016.

Ivancevich, J.M./Schweiger, D.M./Power, F.R. (1987): Strategies for managing human resources during mergers and acquisitions. In: Human Resource Planning, 10(1), 19-35.

Jemison, D.B./Sitkin, S.B. (1986): Corporate acquisitions: a process perspective. In: Academy of Management review, 11(1), 145-163. DOI: 10.5465/AMR.1986.4282648.

Koveshnikov, A./Vaara, E./Ehrnrooth,M. (2016): Stereotype-based managerial identity work in multinational corporations. In: Organization Studies 37(9), 1353-1379. DOI: 10.1177/0170840616634129

Koveshnikov, A./Ehrnrooth,M./Vaara, E. (2017): Headquarter-subsidiary relations in the multinational corporation as a discursive struggle. In: Dörrenbächer, C./Geppert, M. (eds.): Multinational corporations and organization theory: post millennium perspectives (=Research in the Sociology of Organizations 49). Bingley, 233-264.

Kim, J. (2007): Fears of foreign ownership: the old face of economic nationalism. In: SAIS Review of International Affairs, 27(2), 167-177. DOI: 10.1353/sais. 2007.0033.

Kitzinger, C./Wilkinson, S. (1996): Theorizing representing the other. In: Kitzinger, C./Wilkinson, S. (eds.): Representing the other: a feminism and psychology reader. London/Thousand Oaks/New Delhi, 1-32.

Kivijärvi, M./Eriksson, P. (2013): Why should we go to China? The dynamics of generic and context-specific legitimation. In: Academy of Management Proceedings, 2013(1). DOI: 10.5465/ AMBPP.2013.12543.

Knoerich, J. (2010): Gaining from the global ambitions of emerging economy enterprises: an analysis of the decision to sell a German firm to a Chinese acquirer. In: Journal of International Management, 16(2), 177-191. DOI: 10.1016/j. intman.2010.03.008.

Königs, A./Schiereck, D. (2008): Combined in luxury: M\&A announcement effects and capital market integration in Europe. ICFAI Journal of Mergers \& Acquisitions, 5(1), 30-56.

KPMG 2018: Business Destination Germany. Wie die CFOs deutscher Tochtergesellschaften ausländischer Konzerne Deutschland bewerten. Düsseldorf.

Krug, J.A./Nigh, D. (2001): Executive perceptions in foreign and domestic acquisitions: an analysis of foreign ownership and its effect on executive fate. In: Journal of World Business, 36(1), 85-105. DOI: 10.1016/S1090-9516(00)00055-9.

Larsson, R./Finkelstein, S. (1999): Integrating strategic, organizational, and human resource perspectives on mergers and acquisitions: a case survey of synergy realization. In: Organization Science, 10(1), 1-26. DOI: 10.1287/orsc.10.1.1.

Leitner, H./Sheppard, E. (2013): Unbounding critical geographic research on cities: The 1990s and beyond. In: Urban Geography, 24(6), 510-528. DOI: 10.2747/0272-3638.24.6.510.
Little, J. (1999): Otherness, representation and the cultural construction of rurality. In: Progress in Human Geography, 23(3), 437-442.

Lossau, J. (2002): Die Politik der Verortung: eine postkoloniale Reise zu einer anderen Geo-graphie der Welt. Bielefeld.

Macrae, N.C./Bodenhausen, G.V. (2000). Social cognition: Thinking categorically about others. In: Annual Review of Psychology, (51), 93-120. https://doi.org/10.1146/annurev.psych.51.1.93

Madhok, A./Keyhani, M. (2012): Acquisitions as entrepreneurship: asymmetries, opportunities, and the internationalization of multinationals from emerging economies. In: Global Strategy Journal, (2), 26-40.

Mayring, P. (2007): Qualitative Inhaltsanalyse. Grundlagen und Techniken, Weinheim.

McDonald, F./Barry, F./Driffield, N./MacKay, B./Ross, D./Rugman, A./Young, S. (2015): Implications for international business of separatist movements: the case of Scottish independence. In: McDonald, F./Barry, F./Driffield, N./MacKay, B./Ross, D./ Rugman, A./Young, S. (eds.): The rise of multinationals from emerging economies. Achieving a new balance. Houndmills/ Basingstoke, 28-50.

McDowell, L. (2008): Thinking through work: complex inequalities, constructions of difference and trans-national migrants. In: Progress in Human Geography, 32(4), 491-507. DOI: 10.1177/0309132507088116.

Meyer, D./Fuchs, M. (2010): Trade unions as learning organizations? The challenge of attracting temporary staff. In: Bergene, A.C./ Endresen, S.B./Knutsen, H.M. (eds.): Missing Links in Labour Geography. Farnham/Burlington, 99-111.

Öberg, C. (2017): Making sense of local customer relationships in cross-border acquisitions. In: Fuchs, M./Henn, S./Franz, M./Mudambi, R. (eds.): Managing culture and interspace in cross-border investments. Building a Global Company. New York/London, 158-167.

Oevermann, U. (2001): Die Struktur von sozialen Deutungsmustern Versuch einer Aktualisierung. In: Sozialer Sinn, 1, 35-81.

Risberg, A./Tienari, J./Vaara, E. (2003): Making sense of a transnational merger: media texts and the (re)construction of power relations. Culture and Organization, 9(2), 121-137.

Rottig, D./Reus, T.H./Tarba, S.Y. (2013): The impact of culture on mergers and acquisitions: a third of a century of research. In: Cooper, C.L./Finkelstein, S. (eds.): Advances in mergers and acquisitions. Bingley, 135-172. (=Advances in Mergers and Acquisitions 12). DOI: 10.1108.

Sauvant, K.P. (2009): FDI Protectionism is on the rise. Published online. (=World Bank Policy Research Working Paper Series, No. 5052). Available at: https://ssrn.com/abstract=1476694, accessed 25/02/2018.

Schotter, A./Mudambi, R./Doz, Y./Gaur, A. (2017): Boundary spanning in global organizations. In: Journal of Management Studies, 54(4), 403-421. DOI: 10.1111/joms. 12256.

Schulz-Nieswandt, F. (2017): Menschenwürde. Eine dichte Re-Konstruktion der sozialen Exklusion im Lichte der Sakralität der Person. Bielefeld.

Schweiger, D.M./Denisi, A.S. (1991): Communication with employees following a merger: A longitudinal field experiment. In: Academy of Management journal, 34(1), 110-135. DOI: $10.2307 / 256304$.

Si, Y./Liefner, I. (2014): Cognitive distance and obstacles to subsidiary business success - the experience of Chinese 
companies in Germany. In: Tijdschrift voor Economische en Sociale Geografie, 105(3), 285-300. DOI: 10.1111/tesg.12064.

Si, Y./Liefner, I./Wang, T. (2013): Foreign direct investment with Chinese characteristics: a middle path between ownership-location-internalization model and linkage-leverage-learning model. In: Chinese Geographical Science, 23(5), 594-606. DOI: 10.1007/s11769-013-0603-z.

Steinbrink, M. (2012): 'We did the slum!' - Urban poverty tourism in historical perspective. In: Tourism Geographies, 14(2), 213-234. DOI: 10.1080/14616688.2012.633216.

Suwala, L./Kulke, E. (2017): Between embeddedness and otherness: Internationalisation of grocery retailers in emerging markets. In: Fuchs, M./Henn, S./Franz, M./Mudambi, R. (eds.): Managing culture and interspace in cross-border investments: building a global company. New York/London, 146-157.

Torre, A./Rallet, A. (2005): Proximity and localization. In: Regional Studies, 39(1), 47-59. DOI: 10.1080/0034340052000320842.
Vaara, E./Tienari, J. (2011): On the narrative construction of multinational corporations: an antenarative analysis of legitimation and resistance in a cross-border merger. In: Organization Science, 22(2), 370-390.

Valentine, G. (2010): Prejudice: rethinking geographies of oppression. In: Social \& Cultural Geography, 11(6), 519-537. DOI: $10.1080 / 14649365.2010 .497849$.

Van Houtum, H./van Naerssen, T. (2002): Bordering, ordering and othering. In: Tijdschrift voor Economische en Sociale Geografie, 93(2), 125-136. DOI: 10.1111/1467-9663.00189.

Walcott, S.M./Liefner, I. (2017): Chinese outward FDIs in Germany and the U.S.: an assessment of national and subnational location strategies. In: Fuchs, M./Henn, S./Franz, M./ Mudambi, R. (eds.): Managing Culture and Interspace in Cross-border Investments: Building a Global Company. New York/London, 110-121.

Wishard, B.J. (1985): Merger: The human dimension. In: Magazine of Bank Administration, 61(6), 74-79. 